\title{
Cellulase Induction in Three Aspergillus Species Isolated From Artemisia annua L. Plantation Soil Using Different Cellulose Substrates
}

\author{
A. I. Ogbonna (Corresponding author) \\ Department of Plant Science and Technology, University of Jos, Plateau State, Nigeria
}

Tel: 234-803-355-5188. E-mail: ogbonabi@yahoo.co.uk

\section{P. O. Nwadiaro}

Department of Plant Science and Technology, University of Jos, Plateau State, Nigeria

Tel: 234-803-703-3206. E-mail: patnwadiaro@yahoo.com

\begin{abstract}
A. Chuku
Department of Microbiology, Federal University Lafia, Nasarawa State, Nigeria
\end{abstract}

Tel: 234-803-710-0101. E-mail: aleruchichuku@yahoo.com

\author{
C. I. C. Ogbonna
}

Department of Plant Science and Technology, University of Jos, Plateau State, Nigeria Tel: 234-803-381-7606.E-mail: afriheb@yahoo.co.uk

F. C. Onwuliri

Department of Plant Science and Technology, University of Jos, Plateau State, Nigeria Tel: 234-806-530-2804. E-mail: fconwuliri@yahoo.com

Received: December 13, 2014 Accepted: January 15, 2015 Published: January 19, 2015

Doi: 10.5296/jab.v3n1.6738 URL: http://dx.doi.org/10.5296/jab.v3n1.6738 


\section{Abstract}

This study was aimed at isolation and screening of fungal species associated with Artemisia annua Plantation soils from one of the under studied areas in Plateau state, Nigeria for cellulase activity. A total of thirteen fungal species were isolated from various locations within the A. аппиа Plantation and were screened for cellulase production. Agar plate assay was carried out using basal medium supplemented with $1 \%$ Carboxymethylcellulose (CMC) powder and staining with $0.1 \%$ Congo red solution after the incubation period. Among these species, Aspergillus fumigatus, A. niger and A. terreus were more predominant and were recorded as cellulase producing species. They have shown to possess cellulose degrading ability and exhibited maximum zones of hydrolysis on Carboxymethylcellulose medium and were selected for enzyme assay using submerged fermentation (SmF). Enzyme production was analyzed by Dinitrosalicylic acid (DNSA) methods and the enzymes assayed for were CMCase ( $\beta$-1,4-endoglucanase), $\beta$-glucosidase and FPase (total cellulose) using Carboxymethylcellulose, cellulose acetate and Filter paper as substrates respectively. The highest cellulase activity was observed on the $3^{\text {rd }}$ day in $A$. niger with enzyme production of $0.045 \mathrm{IU} / \mathrm{ml}$ and $0.040 \mathrm{IU} / \mathrm{ml}$ on CMC and filter paper media respectively. A. fumigatus had high enzyme activity of $0.037 \mathrm{IU} / \mathrm{ml}$ and $0.025 \mathrm{IU} / \mathrm{ml}$ on filter paper and cellulose acetate media respectively. Highest enzyme production of $0.034 \mathrm{IU} / \mathrm{ml}$ was recorded for $A$. terreus on the $3^{\text {rd }}$ day on cellulose acetate medium. These fungal species could be employed specially to perform in situ environmental applications involving cellulose biodegradation of wastes.

Keywords: Cellulolytic, Artemisia annua, Carboxymethylcellulose, Aspergillus species, Soil, Congo red solution

\section{Introduction}

Cellulose, a renewable source of energy is one of the most abundant organic compounds on earth (Hong et al., 2001). It is a potential raw material for the microbial production of food, fuel and some chemicals (Coral et al., 2002). Several microorganisms utilize it as a source of carbon and it is a major polysaccharide constituent of plant cell walls (Hong et al., 2001). Cellulose is an unbranched glucose polymer and is composed of $\beta-1,4$ glucose units linked

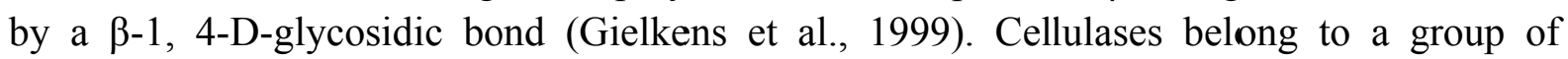
hydrolytic enzymes which catalyze the hydrolysis of cellulose and cellooligosaccharide derivatives into glucose units. Fungal cellulases are extracellular and inducible and consist of three components namely exoglucanase, endoglucanase and $\beta$-glucosidase (Akiba et al., 1995; Wilson \& Irwin, 1999) that act in a synergistic manner to hydrolyze the $\beta-1,4-\mathrm{D}$-glycosidic bonds within the cellulose molecules. The enzymes play important role in natural biodegradation processes in which plant lignocellulosic materials are degraded by a wide variety of microorganisms (Khalid et al., 2006; Peciulyte, 2007; Chinedu et al., 2008). Various bacteria, actinomycetes, protozoa and filamentous fungi produce extra cellular cellulases when grown on cellulosic substrates though many actinomycetes have been reported to have less cellulase activity than fungi (Kluepfel et al., 1986). Streptomyces species have already been identified as good cellulase producers with considerable commercial interests (Chellapandi \& Himanshu, 2008). Aspergillus sp. and Penicillium sp. are generally used for the production of $\beta$-glucosidase, an enzyme necessary for the 


\section{MInstitute Macrothink $^{m}$}

conversion of cellobiose to glucose because these fungi produced only low amounts of endoglucanase (Hamilton \& Was, 1991; Steiner et al., 1994). Enzymatic hydrolysis of cellulose in industrial scales is hindered by the high cost of the enzyme and the low rates of conversion. There have been many researches directed towards finding new microbial sources with efficient endoglucanase synthesis, especially among fungi (Rosgaard et al., 2006). The present study therefore looks at enhancing the extracellular endoglucanase, $\beta$-glucosidase and FPase synthesis under submerged fermentation conditions using three Aspergillus species isolated from Artemisia annua plantation soil.

\section{Materials and Methods}

\subsection{Isolation of Fungi From the Soil Samples}

Soil fungi were isolated from Artemisia annua Plantation in Gangnum, Langtang South Local Government Area of Plateau State, Nigeria using standard microbiological techniques. A weight of $0.03 \mathrm{~g}$ of soil was plated out on Potato Dextrose Agar medium using soil plate method described by Warcup (1950). The medium was supplemented with gentamycin (40 $\mathrm{mg} / \mathrm{ml}$ ) in order to suppress the growth of bacteria. Plates were incubated at room temperature $\left(25 \pm 2^{\circ} \mathrm{C}\right)$ for 5 days. After incubation, small portion of mycelium from each fungal colony was transferred into PDA slants and were kept for further work.

\subsection{Identification of Fungi}

Fungal isolates were identified on the basis of routine cultural and morphological characteristics by comparing them with those that are present in the identification reference manuals (Barnett \& Hunter, 1972; Von Arx, 1974; Onion et al., 1981). Thirteen fungal species were isolated from the experimental soil samples. Most of the isolates, obtained were Aspergillus species which are very dominant in soil natural environment.

\subsection{Plate Assay for Cellulase Enzyme Activity Using Carboxymethylcellulose (CMC) Powder}

Carboxymethylcellulose (CMC) is a substrate for endoglucanase and so was used as a test for $\beta$-1,4-endoglucanase activity. Modified method of Anita et al. (2013) was employed for the assay. Cellulolytic basal medium (1.5 g; Diammonium tartrate $\left(\mathrm{C}_{4} \mathrm{H}_{\mathrm{I} 2} \mathrm{~N}_{2} \mathrm{O}_{6}\right), 0.25 \mathrm{~g}$; Potassium dihydrogen phosphate $\left(\mathrm{KH}_{2} \mathrm{PO}_{4}\right), 0.02 \mathrm{~g} ; \mathrm{MgSO}_{4} .7 \mathrm{H}_{2} \mathrm{O}, 0.0002 \mathrm{~g} ; \mathrm{CaCl}_{2} .2 \mathrm{H}_{2} \mathrm{O}$ $(\mathrm{g} / 250 \mathrm{~mL}$ in distilled water) was prepared, supplemented with $2 \% \mathrm{w} / \mathrm{v}$ of low viscosity CMC and $1.5 \% \mathrm{w} / \mathrm{v}$ agar, autoclaved at $121^{\circ} \mathrm{C}$ at $15 \mathrm{psi}$ for 15 minutes and then transferred aseptically into sterile Petri dishes. The fungal isolates were point inoculated and incubated at $25 \pm 2^{\circ} \mathrm{C}$ in a stationary position for 7 days. Agar plates were stained with $0.1 \%$ Congo red for 15 minutes. Plates were decanted and agar surface was washed with distilled water. The plates were destained by flooding with $1 \mathrm{M} \mathrm{Nacl}$ for 15 minutes. Halo zones of hydrolysis $(\mathrm{mm})$ were observed, measured and recorded.

\subsection{Enzyme Production Through Submerged State Fermentation Using Filter Paper (Fpase)} for Total Cellulase Activity

Whatman Nolfilter paper used in this assay was almost $100 \%$ cellulose. Cellulolytic basal medium (1.5 g; Diammonium tartrate $\left(\mathrm{C}_{4} \mathrm{H}_{12} \mathrm{~N}_{2} \mathrm{O}_{6}\right), 0.25 \mathrm{~g}$; Potassium dihydrogen phosphate $\left(\mathrm{KH}_{2} \mathrm{PO}_{4}\right), 0.02 \mathrm{~g} ; \mathrm{MgSO}_{4} .7 \mathrm{H}_{2} \mathrm{O}, 0.0002 \mathrm{~g} ; \mathrm{CaCl}_{2} .2 \mathrm{H}_{2} \mathrm{O}(\mathrm{g} / 250 \mathrm{~mL}$ in distilled water) was prepared. A volume of $10 \mathrm{ml}$ aliquots was transferred to $20 \mathrm{ml}$ glass culture bottles and were autoclaved at $121^{\circ} \mathrm{C}$ at $15 \mathrm{psi}$ for 15 minutes. Filter paper strips $(0.5 \mathrm{~cm} \times 0.1 \mathrm{~cm})$ were added 
aseptically to each bottle making sure that all filter paper strips were completely submerged. Samples of test fungi which were previously obtained as pure cultures were inoculated separately and uninoculated bottles were retained as controls (Pointing, 1999). Care was taken that bottle caps were loosely fitted to allow adequate exchange of air. The bottles were incubated at $25 \pm 2{ }^{\circ} \mathrm{C}$ without agitation and were assayed at 3,6 and 9 day intervals using cell free culture supernatant of each of the fungi. Boiled enzyme extract was used as blank and D-glucose as standard. The glucose concentration was determined by DNSA method, as described by Miller (1959). The color that developed was measured at $540 \mathrm{~nm}$ using UV spectrophotometer. The experiment was done in triplicates. One unit of filter paper (FPU) activity was defined as the amount of enzyme-releasing $1 \mu \mathrm{mol}$ of reducing sugar from filter paper per $\mathrm{mL}$ per min.

\subsection{Enzyme Production Through Submerged State Fermentation Using Cellulose Acetate for} $\beta$-glucosidase Activity

This assay uses microcrystalline cellulose acetate powder. Generally microcrystalline cellulose is degraded more slowly than ball-milled or acid swollen cellulose. Cellulose Basal Medium was prepared by incorporating $2 \% \mathrm{w} / \mathrm{v}$ cellulose acetate powder. A volume of $10 \mathrm{ml}$ aliquots was transferred to $20 \mathrm{ml}$ glass culture bottles and were autoclaved at $121^{\circ} \mathrm{C}$ at $15 \mathrm{psi}$ for 15 minutes. Samples of test fungi which were previously obtained as pure cultures were inoculated separately and uninoculated bottles were retained as controls. The bottles were incubated at $25 \pm 2^{\circ} \mathrm{C}$ without agitation and were assayed at 3,6 and 9 day intervals using cell free culture supernatant of each of organisms. Boiled enzyme extract was used as blank and D-glucose as standard. The glucose concentration was determined by DNSA method, as described by Miller (1959). The colour that developed was measured at $540 \mathrm{~nm}$ using UV spectrophotometer. The experiment was done in triplicates. One unit of cellulose ( $\beta$-glucosidase) activity was defined as the amount of enzyme-releasing $1 \mu \mathrm{mol}$ of reducing sugar per ml per min.

\subsection{Enzyme Production Through Submerged State Fermentation Using Carboxymethylcellulose For (Endoglucanase) Activity}

A volume of $10 \mathrm{ml}$ aliquots of prepared Carboxymethylcellulose medium was transferred to $20 \mathrm{ml}$ glass culture bottles and were autoclaved at $121^{\circ} \mathrm{C}$ at $15 \mathrm{psi}$ for 15 minutes. Samples of test fungi which were previously obtained as pure cultures were inoculated separately and uninoculated bottles were retained as controls. The bottles were incubated at $25 \pm 2{ }^{\circ} \mathrm{C}$ without agitation. Carboxymethylcellulase (CMCase) hydrolysed Carboxymethylcellulose to produce free Carboxymethyl glucose units. The free Carboxymethyl glucose units reacted with 3, 5-dinitrosalicylic acid (DNSA) reagent to form coloured complex which was detected spectrophotometrically at $540 \mathrm{~nm}$ (Wood \& Garcia-Campayo, 1990). This was assayed at 3,6 and 9 day intervals using cell free culture supernatant of each of the test organisms. Boiled enzyme extract was used as blank and D-glucose as standard. One unit of cellulose ( $\beta$-glucosidase) activity was defined as the amount of enzyme-releasing $1 \mu \mathrm{mol}$ of reducing sugar per ml per min.

\subsection{Statistical Analysis}

The analyses done using plate assay for cellulase enzyme activity were performed on at least 


\section{Macrothink}

three replicates. All the data obtained were subjected to analysis of variance (ANOVA) using Statistical Package for Social Sciences (SPSS). Duncan multiple range test was used to compare the means at $P \leq 0.05$.

\section{Results}

\subsection{Fungal Isolates}

The selected fungi were isolated from soils of Artemisia annua Plantation using Potato Dextrose Agar medium and were identified as Aspergillus fumigatus, A. niger and A. terreus by morphology. Colonies of $A$. fumigatus appeared grayish green and the reverse light yellow. No pigmentation was observed. Growth rate was rapid. Microscopic view showed smooth walled conidiophores, uniserriate and pyriform vesicle, metulae covering upper $2 / 3$ portion of the vesicle as shown in Figure 1a. The conidia looked small, smooth and the conidiation was strongly columnar.

A. niger colonies were predominantly black. The reverse was colourless to light yellow. Pigmentation was absent. The conidiophores were long and smooth. Vesicles were large in size, biserriate with metulae covering the entire surface forming radiate head. The conidia were very rough, spiny and globose. The results are shown in Figures $1 b$.

Colonies of $A$. terreus were beige to buff to cinnamon. The reverse was colourless to light brown. Growth rate is rapid. Colonies become finely granular with massive conidial production. These features with the microscopic observation of A. terreus are depicted in Figure 1c. Hyphae were septate and hyaline. Conidial heads were biserriate and columnar. Conidiophores were smooth-walled and hyaline terminating in mostly globose vesicles. Conidia were small, globose, and smooth.
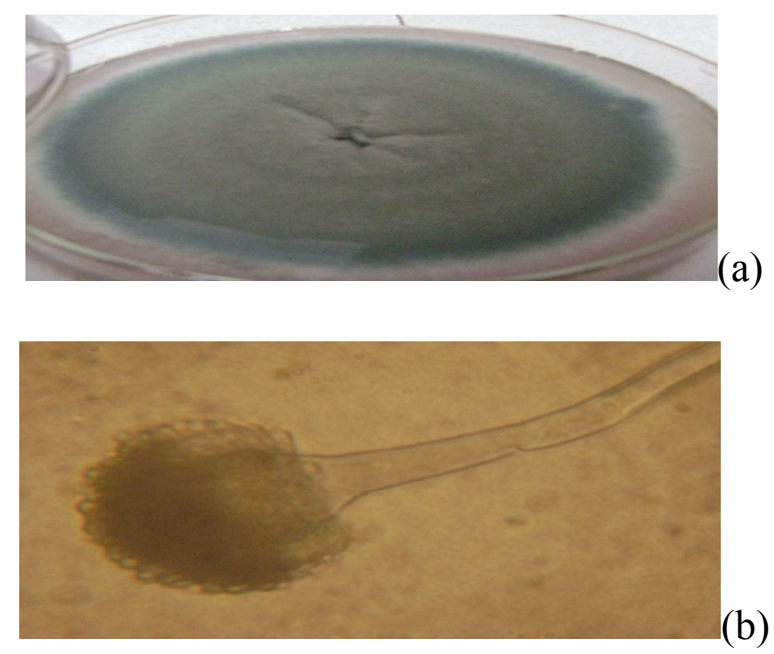

Figure 1a. Aspergillus fumigatus (a) colony (b) microscopic view 

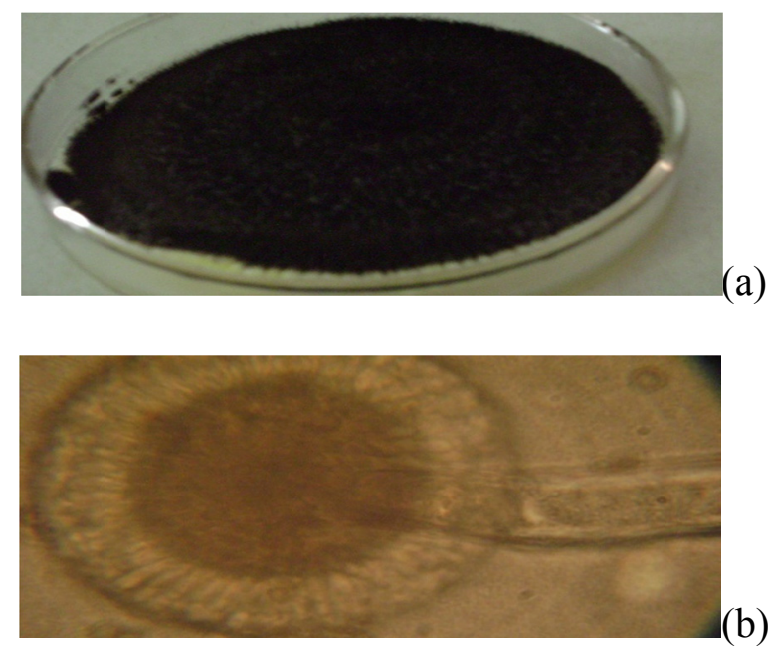

Figure 1b. A. niger (a) colony and (b) microscopic view
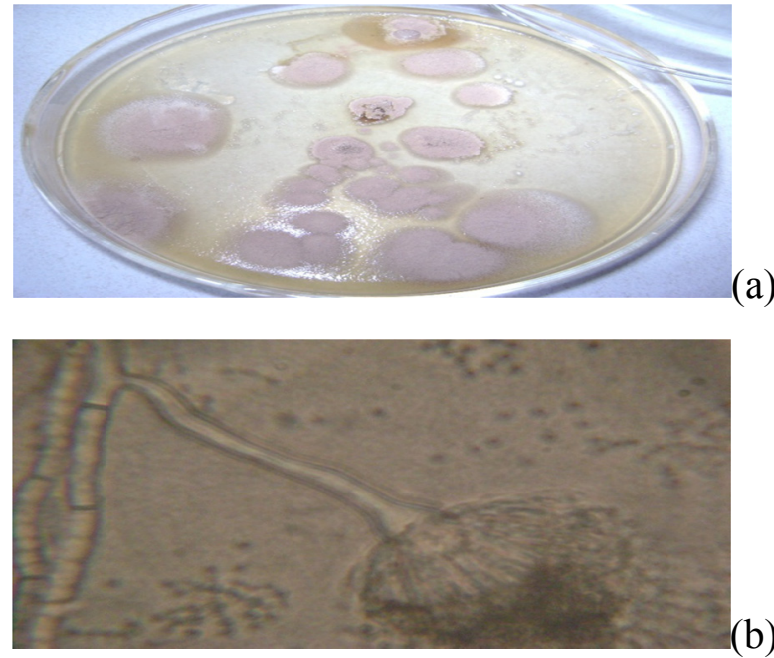

(b)

Figure 1c. A. terreus (a) colony and (b) microscopic view

\subsection{Plate Screening for Cellulase Enzyme Activity}

The screening of the isolated fungi for cellulose degrading activity was carried out on CMC medium. The appearance of the clear zone around the colony after the addition of Congo red solution was strong evidence for secretion of cellulase enzyme. Out of 13 fungal species (result not shown), only three fungi (Aspergillus fumigatus, A. niger and A. terreus) exhibited considerable activity to degrade the Carboxymethylcellulose substrate as depicted in Table 2. There was a significant difference on the mean diameter of clear zones produced by the three selected fungi. The highest zone of clearance was recorded for Aspergillus fumigatus $(83.3 \pm$ $3.06 \mathrm{~mm})$ followed by $A$. niger $(80.0 \pm 4.00 \mathrm{~mm})$ and then $A$. terreus $(67.0 \pm 4.58 \mathrm{~mm})$. Therefore, they were selected for further experimentation. 


\section{Macrothink}

Table1. Cellulolytic activity of the test fungi using CarboxymethylCellulose agar $(\mathrm{Mean} \pm \mathrm{SE})$

\section{Test organisms Mean diameter of Clearing (mm) Activity Level}

$\begin{array}{ccc}\text { Aspergillus fumigatus } & *+++ & 83.3 \pm 3.06^{a} \\ \text { A. niger } & +++ & 80.0 \pm 4.00^{\mathrm{a}} \\ \text { A. terreus } & +++ & 67.0 \pm 4.58^{b}\end{array}$

Figures in the same column having the same superscript are not significantly different $(\mathrm{p} \leq 0.05) ;+++=$ strongly cellulolytic.

\subsection{Enzyme Production Through Submerged State Fermentation}

The selected fungal isolates were found to degrade various cellulosic substrates in liquid state fermentation. Maximal CarboxyMethylCellulase (CMCase) and FilterPaperase (FPase) production was obtained from Aspergillus niger $(0.045 \mathrm{IU} / \mathrm{ml}$ and $0.040 \mathrm{IU} / \mathrm{ml}$ respectively) after the first three days of incubation (Figure 2), after which the activity reduced drastically on $6^{\text {th }}$ and $9^{\text {th }}$ days of incubation. A. fumigatus had a higher FPase production of $0.037 \mathrm{IU} / \mathrm{ml}$ to that of CMCase production $(0.016 \mathrm{IU} / \mathrm{ml})$ after the first three days. The activity declined after $6^{\text {th }}$ day of incubation and remained steady up to the $9^{\text {th }}$ day of incubation (Figure 3 ). The least enzyme production was observed in A. terreus for CMCase and FPase $(0.018 \mathrm{IU} / \mathrm{ml}$ and $0.011 \mathrm{IU} / \mathrm{ml}$ ) respectively after the $3^{\text {rd }}$ day but showed a higher activity for $\beta$-glucosidase than $A$. niger and A. fumigatus. A. terreus had CMCase and FPase activity that was significantly lower than that of $A$. niger and A. fumigatus. As was observed, it took A. terreus 9 days to reach its peak of hydrolysis for CarboxyMethylCellulase (CMCase). The results are depicted in Figures 2-4.

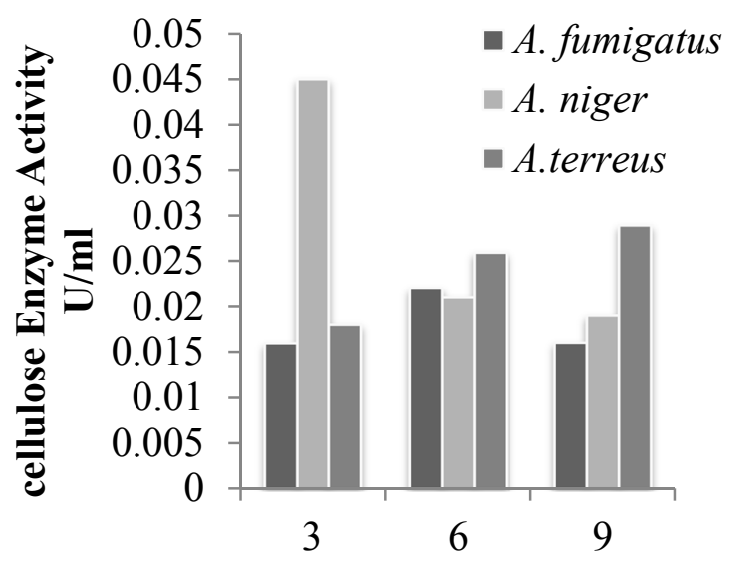

Days

Figure 2. Cellulase production by A. fumigatus, A. niger and A. terreus at different periods of incubation on Carboxymethylcellulose medium 


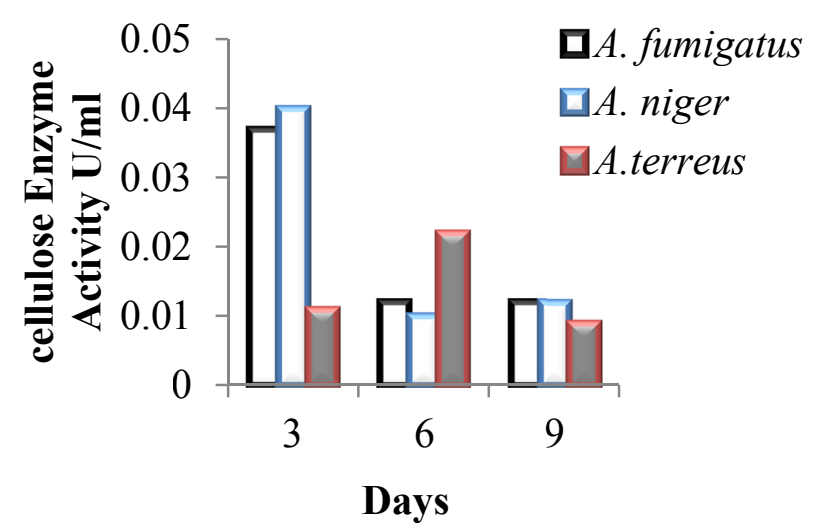

Figure 3. Cellulase production by A. fumigatus, A. niger and A.terreus at different periods of incubation on filter paper medium

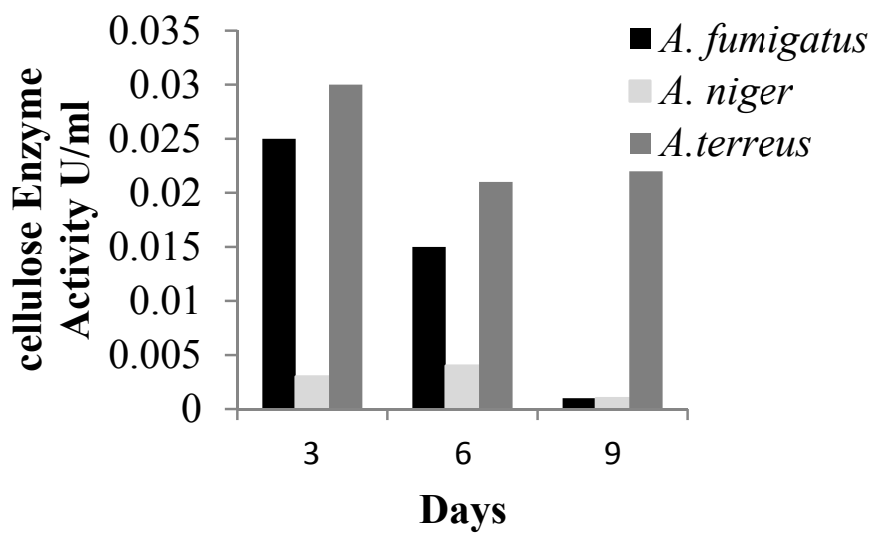

Figure 4. Cellulase production by A. fumigatus, A. niger and A. terreus at different periods of incubation on cellulose acetate medium

\section{Discussion}

\subsection{Isolated Fungal Species}

The three fungal species used in this research work were selected from various species that were isolated from soil of $A$. annua plantation. The selection stemmed from the fact that the rate and frequency of growth recorded for them were higher than those of other isolated species. The genus Aspergillus has been reported to be the most dominant among other species isolated from different natural habitats (Mukunda et al., 2012; Uttam et al., 2014). It is believed to be as a result of their abilities to grow fast on any available substrate due to their elaboration of hydrolytic enzymes that enable them breakdown the substrates they found themselves on.

5.2 Enzyme Activity of the Fungal Isolates on Plate Assay and Submerged State Fermentation (Smf)

The plate assay for the hydrolysis of Carboxymethylcellulose used as carbon source showed 
that the three selected fungi hydrolysed the substrates at different rates (Table 1). A fumigatus was found to be the best hydrolyzer of the CMC substrate on solid state with zone of clearance of $83.3 \mathrm{~mm}$. A. fumigatus is a known cellulase producer. The results are in consonance with that of Sathyaprabha et al. (2011) who reported cellulase production in $A$. fumigatus, $A$. versicolor, $A$. nidulans and $A$. niger.

In submerged state fermentation for the production of cellulase, the selected fungi were inoculated separately in $100 \mathrm{~mL}$ fermentation media in $250 \mathrm{~mL}$ capacity flasks. The fungi utilized the media for their growth and secreted various secondary metabolites including cellulases into the culture flasks. The enzyme quantities were expected to increase with increase in fungal growth and incubation period. Therefore, the crude extract from the fermentation media was harvested at the interval of 3 days up to 9 days. The cultivation time allows for maximum growth of microorganisms and product formation to a certain degree in a fermentation system. In the submerged fermentation $(\mathrm{SmF}), A$. niger was observed to have an enzyme activity $(0.045 \mathrm{IU} / \mathrm{ml})$ that was significantly higher than that of $A$. fumigatus $(0.016 \mathrm{IU} / \mathrm{ml})$ on the first three days of incubation and was observed as the peak for both species, after which enzyme activity dropped up to the ninth day of incubation (Figures 2 and 3). Explanation to this could be difficult since many factors including media composition, fermentation type and choice of substrate affect enzyme production and activity as reported by Sharma and Sreekantiah (1986). The results as presented in Figures 2 and 3 also indicated that $A$. niger showed a higher CMCase and FPase than A. fumigatus and A. terreus. The CMCase and FPase activity of $A$. niger and $A$. fumigatus were very rapid due to increase in cellulose utilization in the two fungal species and as such reached their peak enzyme activity on the $3^{\text {rd }}$ day of fermentation. Aspergillus species especially A. niger have been reported as fast growing fungi (Oyeyiola \& Hussein, 1992; Utamm et al., 2014).

$A$. terreus exhibited $\beta$-glucosidase activity that was significantly higher than that $A$. niger and $A$. fumigatus. Cellulose acetate is known to have an additional acetyl group and requires the presence of esterases for its first step in biodegradation. The enzyme system of $A$. terreus probably could be equipped with acetyl esterase enzyme which performs the deacetylation step in cellulose acetate hydrolysis, which then allowed the polymer's cellulose backbone to be readily biodegraded by the selected test fungi. A. terreus had peak $\beta$-glucosidase enzyme activity of $0.030 \mathrm{IU} / \mathrm{ml}$ for cellulose acetate after the $3^{\text {rd }}$ day of incubation. This was followed by $A$. fumigatus and $A$. niger with peak enzyme activity of $0.025 \mathrm{IU} / \mathrm{ml}$ and $0.003 \mathrm{IU} / \mathrm{ml}$ respectively after the $3^{\text {rd }}$ day of incubation. The present finding indicates that the enzyme systems of these fungal forms contain enzymes complexes ( $\beta$-glucosidase, CMCase (Endoglucanase) and FPase) for the effective hydrolysis of cellulose (Ali et al., 1991; Jahangeer et al., 2005). The cellulose degrading potential of $A$. terreus has been reported previously (Ali et al., 1991; Szakacs et al., 2001).

The results of the present research work showed that the selected test fungi had different cellulose degrading ability for the different cellulose substrates (Carboxymethylcellulose, Filter paper and cellulose acetate) used in the study. This result coincides with the findings of Sivakumaran, (2014) in his work on isolation of cellulolytic fungi and their degradation on cellulosic agricultural wastes. This result is relevant to the given physical and chemical conditions because, the activity of each fungal enzyme varies according to its individual 
preference to the substrate, chemical nature of the medium, optimal temperature, and $\mathrm{pH}$ conditions. These factors are important in determining the survival of certain fungus on natural environment. If such factors are more suitable for a particular species, that species will ultimately win the competition on using all the resources more than the others and the later are eventually eliminated. However, some fungi can produce specialized structures to survive in such harsh conditions and will germinate when environmental conditions become favourable to them (Sivakumaran, 2014).

\section{Conclusion}

Conclusively, fungi generally are known agents of decomposition of cellulose and other substrate containing organic matter using their complex enzyme system. The enzyme system of the fungal species used in this research work could be employed in the decomposition of Artemisia annua process wastes in the plantation, thereby improving the humus content of the plantation soil.

\section{Acknowledgement}

Authors are thankful to the authorities of National Veterinary Research Institute (N.V.R.I.) Vom and Department of Plant Science \& Technology, University of Jos for their scientific help.

\section{References}

Akiba, S., Kimura, Y., Yamamoto, K., \& Kumagai, H. (1995). Purification and characterization of a protease-resistant cellulase from Aspergillus niger. J. Ferment. Bioeng, 79(2), 125-130. http://dx.doi.org/10.1016/0922-338X(95)94078-6

Ali, S., Sayed, A., Sarker, R. I., \& Alam, R. (1991). Factors affecting cellulose production by Aspergillus terreus using water hyacinth. World J. Microbiol and Biotechnol, 7, 62-66.

Anita, B. B., Thatheyus, A. J., \& Vidhya, R. (2013). Biodegradation of Carboxymethyl Cellulose Employing Cheatomium globosum MTCC 2193. Science International, 1, 92-97. http://dx.doi.org/10.5567/sciint1.2013.92.97

Barnett, H. L., \& Hunter, B. B. (1972). Illustrated genera of Imperfect Fungi, Burgress Publishing Company, Minneapolis, Minnesota, USA. p. 241.

Chellapandi, P., \& Himanshu, M. J. (2008). Production of endoglucanase by the native strains of Streptomyces isolates in submerged fermentation. Brazilian J Microbiol, 39, 122-127. http://dx.doi.org/10.1590/S1517-83822008000100026

Chinedu, S. N., Nwinyi O. C., \& Okochi, V. I. (2008). Growth and cellulose activity of wild-type Aspergillus niger ANL301 in different carbon sources. Can. J. Pure Appl. Sci., 2, 357-362.

Coral, G., Arikan, B., Unaldi, M. N., \& Guvenmes, H. (2002). Some properties of crude carboxymethylcellulase of Aspergillus niger Z10 wild-type Strain. Turk J. Biol, 26, 209-213.

Gielkens, M. M. C., Dekkers, E., Visser, J., \& Graaff, L. H. (1999). Two cellubiosehydrolase-encoding genes from Aspergillus niger require D Xylose and the xylanolytic transcriptional activator $\mathrm{X} \ln \mathrm{R}$ for their expression. Appl. Environ. Microbiol, 65(10), 4340-4345.

Hamilton, J. A., \& Was, D. (1991). Some components of cellulases from two different strains 
of Aspergillus fumigatus. Process Biochem, 26, 287-290.

http://dx.doi.org/10.1016/0032-9592(91)85016-H

Hong, J., Tamaki, H., Akiba, S., Yamamoto, K., \& Kumaga, H. (2001). Cloning of a gene encoding a highly stable endo1,4-glucanase from Aspergillus niger and Its expression in Yeast. J. Biosci. Bioeng, 92(5), 434-441. http://dx.doi.org/10.1016/S1389-11723(01)80292-9

Khalid, M., Yang, W. J., Kishwar, N., Rajput, Z. I., \& Arijo, A. G. (2006). Study of cellulolytic soil fungi and two nova species and new medium. J. Zhejiang Univ. Sci. B, 7(6), 459-466. http://dx.doi.org/10.1631/jzus.2006.B0459

Kluepfel, D., Shareck, F., Mondou, F., \& Morosoli, R. (1986). Characterization of cellulase and xylanase activities of Streptomyces lividans.Applied Microbiol.Biotechnol, 24, 230-234. http://dx.doi.org/10.1007/BF00261542

Miller, G. L. (1959). Use of Dinitrosalicyclic reagent for the determination of reducing sugars. Anal. Chem, 31, 426-428. http://dx.doi.org/10.1021/ac60147a030

Mukunda, S., Onkarappa, R., \& Prashith, K. T. R. (2012). Isolation and Screening of Industrially Important Fungi from the Soils of Western Ghats of Agumbe and Koppa, Karnataka, India. Science, Technology and Arts Research Journal, 1(4), 27-32. http://dx.doi.org/10.4314/star.v1i4.98816

Onion, A. H. S., Allsop, D., \& Eggins, H. O. W. (1981). Smiths Introduction to Industrial mycology (7th Ed.)Edward-Arnold Publishers Ltd. London. p. 398.

Oyeyiola, G. P., \& Hussein, H. S. N. (1992). Fungi populations in the rhizosphere and rhizoplane of wheat grown in Kura Area of Kan, Northern Nigeria. Bioscience Research Communications, 4(2), 129-133.

Peciulyte, D., (2007). Isolation of cellulolytic fungi from waste paper gradual recycling materials. Ekologija, 53, 11-18.

Pointing, S. B. (1999). Qualitative methods for the determination of lignocellulolytic enzyme production by tropical fungi. Fungal Diversity, 2, 17-33.

Rosgaard, L., Pedersen, S., Cherry, J. R., Harris, P., \& Meyer, A. S. (2006). Efficiency of new fungal cellulose systems in boosting enzymatic degradation of barley straw lignocelluloses. Biotechnol Prog, 22(2), 493-498. http://dx.doi.org/10.1021/bp050361o

Sathyaprabha, G., Panneerselvam, A., \& Muthukkumarasamy, S. (2011). Production of Cellulase and Amylase from wild and mutated fungal isolates. E-Journal of Life Sciences, 1(1), 39-45.

Sharma, T. R., \& Sreekantiah, K. R. (1986). Production of cellulases and D-Xylanase by some selected fungal isolates. Enzyme Microbiol Technol, 8, 178-182. http://dx.doi.org/10.1016/0141-0229(86)90109-2

Sivakumaran, S. (2014). Isolation of Cellulolytic Fungi and their Degradation on Cellulosic Agricultural Wastes. Journal of Academia and Industrial Research, 2(8), 458-463.

Steiner, J., Socha, C., \& Eyzaguirre, J., (1994). Culture conditions for enhanced cellulase production by a native strain of Penicillium purpurogen. World J Microbiol Biotechnol, 10, 280-284. http://dx.doi.org/10.1007/BF00414863

Szakacs, G., Boagar, B., Molnar, T., Szilagi, E., Fekete, J., \& Tengerdy, R. P. (2001). 


\section{Macrothink}

Optimization of $\alpha$ - amylase and lovasatin production in solid substrate fermentation. In Intl Conf. on New Horizons in Biotechnol ,Trivandram, India. pp. 18-21.

Uttam, K., Ashwani, T., Pinky, K., Shiju, V., \& Suresh, C. (2014). Isolation and Screening of Cellulase Producing Fungi from Forest Waste. International Journal of Pharmaceutical \& Biological Archives, 5(1), 56-59.

Von Arx, J. A. (1974). The Genera of Fungi sporulating in pure culture. Publ. J. Grammar. In der A. R. Gantner Verlog Kommanditesellschaft, Fl- 9490 Vaduz, Germany. p. 315.

Warcup, J. H. (1950). The soil plate method for isolation of fungi from soil. Nature, 166, 117-118. http://dx.doi.org/10.1038/166117b0

Wilson, D. B., \& Irwin, D. C. (1999). Genetics and properties of cellulases. Advances in Biochemical Engineering/ Bio-technology: Recent Progress in Bioconversion, 65, 1-21. http://dx.doi.org/10.1007/3-540-49194-5_1

Wood, T. M., \& Garcia-Campayo,V. (1990). Enzymology of cellulose degradation. Biodegradation, 1, 147-161. http://dx.doi.org/10.1007/BF00058833

\section{Copyright Disclaimer}

Copyright reserved by the author(s).

This article is an open-access article distributed under the terms and conditions of the Creative Commons Attribution license (http://creativecommons.org/licenses/by/3.0/). 